\title{
Chinese Perception of European Perspective: A Jesuit Case in the Seventeenth Century
}

\section{Preface: A Cross-Cultural Concern}

The late-Ming master of literati Dong Qichang 董其昌 (1555-1636) commented on the relationship between nature and painting, as quoted and translated by James Cahill: 'From the standpoint of splendid scenery, painting cannot equal [real] landscape. But from the standpoint of the sheer marvels of brush and ink, [real] landscape is not at all the equal of painting.' ${ }^{1}$ This early-seventeenth-century remark about Chinese landscape painting demonstrates the mutually irreplaceable status of nature and painting as reflected in contemporary artistic discourse. However, in the European Renaissance, Leon Battista Alberti (1404-72) and Leonardo da Vinci (1452-1519) claimed that painting not only derives from nature but can also imitate it, through science. Speaking of composition in painting, for example, Alberti states in his treatise that, as for the movements of the body, the painter 'must take from Nature with great skill'. Painters must work 'with the greatest diligence from Nature and always directly imitated, preferring those in painting which leave more for the mind to discover than is actually apparent to the eye'. In Alberti's De Pictura (1435), this first treatise on linear perspective for painting, the author claims at the outset that he wants 'to explain the art of painting from the basic principles of nature'. ${ }^{2}$

The above comparison between the two different methods of painting does not exclude the possibility that Dong thought of painting in the sense of its being able to imitate nature. However, the intermediary role that science played between art and nature in the Renaissance was not evident in China. Perspective is a scientific theory derived from the ancients and a 'geometric-optical way of picture making'. ${ }^{3}$ It was revived and formulated in Renaissance art as a special pictorial construction of 'linear perspective'. In its tradition in classical antiquity, it derived from the application of geometrical laws to analyze human vision. As Leonardo states, perspective is a science originating from arithmetic and geometry, devoted to all the functions of the 
human eye. ${ }^{4}$ Art and science were perceived to be interlinked in European intellectual circles, a perception that lasted into the seventeenth century. ${ }^{5}$ 'Nothing can be found in nature that is not part of science': this statement by Leonardo clearly expresses the foundation for the interlinking of art and science. ${ }^{6}$ So, Leonardo continued to explain painting in terms of scientific thinking as follows: 'No human investigation may claim to be a true science if it has not passed through mathematical demonstrations. ${ }^{\text {"7 }}$ Dong's writings, on the other hand, teach one to 'observe' nature carefully, but not in the sense of imitation and scientific analysis. Dong's 'considering heaven and earth [the natural realm] as teacher (以天地為師)' urges painters to attempt to catch the spirit of nature and accommodate that into painting. ${ }^{8}$ This can be seen as an axiom of traditional Chinese pictorial theories, so that the solely physical imitation of nature was never appreciated in their traditions. Although the following statement of Samuel Edgerton is not necessarily correct in content, it illustrates that the intellectual discourse shared by art and science in Europe is not to be found in China. It is, therefore, an important premise on which to contextualize the transmission of European perspective to this country:

In fact, by Western standards, it is hard to comprehend how Chinese science and technology was $[s i c]$ able to progress at all with so little involvement of artists or pictures. $^{9}$

Martin Kemp proposes, instead, a complex of reciprocity between works of art and scientific concepts from the Renaissance era onward, instead of an a priori or an a posteriori relationship. ${ }^{10}$

From the Quattrocento onward, Renaissance perspective indicated not only technological invention for artistic spatial construction. Those issues surrounding it with regard to the reciprocal relationship between art and science, and even the controversies on the nature of visual representation, are prominent and crucial for the whole course of Western historical evolution. ${ }^{11}$ As Martin Kemp states, no Western European artists after the fifteenth century could be considered as 'on an international scale without a sound grasp of the basic technique [of perspective]'. ${ }^{12}$ So, recognizing that perspective is 'a factor of style', Erwin Panofsky has shown that to write the history of Western art is also to write a history of perspective. ${ }^{13}$ Since it was an essential element of Western pictorial representation, perspective became an ethnological product. In his discussion of the Renaissance 'rediscovery' of linear perspective, Edgerton intends to relate the reason for the appearance of Filippo Brunelleschi's (1377-1446) initial perspectival demonstration to 'the particular anthropological and psychological needs of a given culture'. ${ }^{14}$ If the resurgence of linear perspective can be regarded as the product of the special Renaissance environment, it is intriguing to apply an anthropological and psychological view to investigate the diffusion of perspective which occurred in non-European countries after $1500 .^{15}$ 
Therefore, the intention of this article is to situate a study of the diffusion of perspective in a comparative context. Based on the above-named scholarly works, it offers a non-European comparison found in the Jesuit China missions. However, the premise of this comparison is opposed to one statement that Edgerton made for his term 'rediscovery'. According to Edgerton, " "Discover" implies that linear perspective is an absolute scientific truth, universal to all men regardless of cultural background or historical period' ${ }^{16}$ It could be said that perspective showed a scientific exactitude in a sense, but it was an exactitude not universally realized by seventeenth-century Chinese people. It is also interesting to note, however, that the Chinese perception of European perspective explains an impression this foreign skill caused on the Chinese way of seeing. Unlike most of the European audience, who were supposed to be aware of the theoretical background and knowledge of perspective, the Chinese people were not aware of this background. As I will argue, the Chinese perception of perspective was closely associated with the broader missionary and cultural frameworks. Moreover, this research also hopes to promote a partial contribution of a cross-cultural observation from a non-Western culture to an understanding of a dominant Western style.

\section{Why the Seventeenth Century?}

Previous scholarship on Jesuit art in China rarely discusses the early period of the mission in a careful way. Although, in the literature, perspective has been recognized as the core theme, the encounters and conflicts concerning the interrelationship between European art/science and local traditions have not been fully articulated. ${ }^{17}$ This is due, to some extent, to the presumption that in the early period of the Jesuit missions, European art had no substantial effect on native traditions. Scholars tend to pay more attention to the latter part of the century, and particularly the eighteenth century, as Chinese sources describing amazement at, or condemnation of, perspective were more plentiful then, and missionary artists at court had become a notable group. ${ }^{18}$ However, the questions about perspective raised during the early Jesuit China missions - i.e., down to around the mid-seventeenth century - need to be examined because this period was the earliest and most crucial in the formation of the Jesuit missions in China. The first dynamic contact between Europe and China in the post-Tridentine era also occurred during this time. Nor did the history and nature of the Jesuit missions remain unchanged from the seventeenth to the eighteenth centuries, so the Chinese responses to perspective in the former century should be addressed in their historical backgrounds.

The work of James Cahill is the only prominent exception, as the strongest proponent of the explicit influence of European perspective on Chinese artistic traditions. ${ }^{19}$ Cahill's is the sole statement relating the pivotal position 
of the early-seventeenth-century period to the encounters of pictorial traditions between China and Europe, and it is a powerful one. His assertion is related to his own argument that the first half of the seventeenth century demonstrated a variety of artistic interests in an era ready to receive and digest the foreign motifs and styles introduced by the Jesuits. ${ }^{20}$ His argument, valid and right in a sense, supports the present focus on the period in question:

It may seem odd to locate the major effect of Western styles on Chinese painting in the late Ming and early Ch'ing, since their influence has been most widely recognized for a later period, the eighteenth century. In that later period, the influence appears in obviously Europeanized painting by the masters of the K'ang-hsi [Kangxi], Yung-cheng [Yongzheng], and Ch'ien-lung [Qianlong] court academies, and coincides with the practice of similarly hybrid styles by Giuseppe Castiglione (known to the Chinese as Lang Shih-ning) and other foreign painters working in the Manchu court. But by that time the period of most significant Western influence was largely over; it had already penetrated and been absorbed or rejected by masters of greater artistic stature than the eighteenth century was to produce. The much-discussed emergence of Sino-European styles in the eighteenth century is a relatively minor phenomenon, making up a brief chapter in Ch'ing cultural history and a briefer one in art history. By concentrating on it, studies of the impact of European styles on later Chinese painting have mostly missed the real point. ${ }^{21}$

Whether or not the first half of the seventeenth century played such a weighty part in the assimilation of European artistic style in China is still debatable. As I will discuss further, the Chinese impression of perspective reveals a complex of illusion / realism in the seventeenth century, and it may have demonstrated a profound perception in a religious realm.

Another reason that scholars rarely pay careful attention to the early period of the Jesuit missions is largely because of the lack of a systematic investigation of the relevant visual materials from the period. ${ }^{22}$ Cahill's study is impressive, but the question arises in the very sources he relied on and cited. It has been thought that Braun and Hogenberg's Civitates Orbis Terrarum was in Nanjing 南京 by 1608; this was asserted initially by Michael Sullivan, who cited the account of the Jesuit Matteo Ricci (1552-1610). ${ }^{23}$ Cahill used this work much more than he did Abraham Ortelius's Theatrum orbis terrarium, which was certainly brought to China and found in Beitang's 北堂 catalogue of the Jesuit library. ${ }^{24}$ However, we find that Ricci never mentioned the title of Braun and Hogenberg's Civitates Orbis Terrarum in his account, and we cannot actually be sure that this work came to China via the Jesuits, as it is not mentioned in Beitang's catalogue either. There were no other sources about this work coming to China at that time. Because the history of the sources Cahill uses is undefined, he could only rightly say, at the most, that the European works he discussed might have been seen by the Chinese, because they were believed to have arrived in China by the date in question. 


\section{The Jesuits and Perspective in China}

Perspective became an issue in China when the Jesuits first reacted to Chinese artistic traditions. The earliest record of this is in a letter by the Jesuit Niccolò Longobardo (1565-1655) to General Claudio Aquaviva, dated 18 October 1598. Longobardo commented on the respect of the Chinese for all the European books and images that the missionaries showed them. According to Longobardo, the Chinese saw these images as skillful and delicate, since they had incorporated shadows (ombre) that Chinese paintings did not have. ${ }^{25}$ The use of shadow - that is, the skill of chiaroscuro - was part of Renaissance perspective. In the year 1598, Longobardo was preaching in Shaozhou 韶州, a prefecture of the Province of Guangdong (廣東省). Immediately afterward, in 1599, he began preaching and contacting common people and villagers face-to-face in rural areas surrounding the town. ${ }^{26}$ The Jesuit Matteo Ricci's comments on Chinese art appeared in his own account and again related a remark similar to Longobardo's. Because the Chinese knew neither painting in oil nor the rendering of shadow, Ricci states, their paintings are pale and dull, lacking vividness (smorte e senza nessuna vivezza). Additionally, Chinese paintings done by famous people were only rendered in ink without colours (pintura di persone famose, senza colori, ma di solo inchiostro). This Jesuit opinion - in response to the question the Chinese in Nanjing asked Ricci as to how Western paintings could attain their lifelike visual effect - was translated fully into Chinese, and was recorded in Gu Qiyuan's 顧起元 (1565-1628) Ke zuo zhui yu 客座贅語 (c. 1618):

利瑪竇, 西洋歐邏巴國人也...來南京居正陽門西營中, 自言其國以崇奉天主為 道, 天主者, 制匠天地萬物者也。所畫天主, 乃一小兒, 一婦人抱之曰天母。 畫以銅板為幀, 而塗五采於上。其貌如生, 身與臂手, 儼然隱起幀上, 臉之凹 凸處, 正視與生人不殊。人問畫何以致此? 答曰：「中國畫但畫陽不畫陰, 故 看之人面軀正平，無凹凸相。吾國畫兼陰與陽寫之，故面有高下，而手臂皆輪 圓耳。」

Matteo Ricci, a European of the Western Ocean ... came to Nanjing, and staying in the western quarter of the Gate of Zheng-yang, said that his country regarded the devotion to the Heavenly Lord as the principle of their worship. The Heavenly Lord is the Creator and Governor of the universe and all things. The Lord was depicted as a child, and the woman holding it was called the Mother of the Lord. The image was carried out on a copper plate, then coloured. It appeared like a living being. The body, arms and hands looked as though they were coming out of the plate, and the facial concavity and convexity were seen exactly the same as if they were alive. People asked how the image could be so, and he said: 'Chinese painting only depicts the convexity, so the body and face of the image appears to be straight and flat, without the concavity and convexity. The painting of our country depicts both concavity and convexity, so the face of the image has differences, and the arms and hands can be rounded. ${ }^{27}$ 
The Chinese accounts usually showed the impression on the Chinese mind of the pictorial advance of Western chiaroscuro, and the Chinese admiration of this skill, which rightly correspond to the missionaries' remarks on Chinese art. ${ }^{28}$ Here is a concrete example showing the way in which Renaissance thought was embedded in Jesuit knowledge and, further, was applied to a one-dimensional judgment of non-Western arts on the part of the missionaries. The view of the inferiority of Chinese painting and artifice was an exception to the seventeenth-century Jesuits' admiration of Chinese culture in general.

Furthermore, Jesuit cartography in China is also part of the story of perspective in China, since it raised the visual problem of perspectival construction on a flat surface for the Chinese people. The first written record detailing a direct response to this new visual material also explains the viewer's amazement at the new visual format, derived from the Western capacity of rendering the world on a flat surface. ${ }^{29}$ There is a Jesuit description of the Chinese response to perspective, which reflects a similar perception of the degree of technical skill:

Really, there comes no end to their admiration [when they see] how such deep backgrounds with roads, porches, courtyards, columns and all other things can be conjured up on the absolutely flat surface of a canvas, and so close to reality that many of them - who have never seen or heard of such things before - were totally deluded when suddenly confronted at a fairly great distance with such paintings of houses and gardens and thought they were seeing real houses and gardens! ${ }^{30}$

The above text comes from a Latin work entitled Astronomia Europaea (European Astronomy), composed by the Jesuit Ferdinand Verbiest (16231688). It is aimed at the European reader, and introduces the story of the revival of European astronomy in China around 1668 to 1669 . This work was supposed to have been drafted up to around the 1680s, and was published in Dillingen, Germany in 1687. The chapter on perspective in the book tells how this skill attracted and amazed the emperor and the general public. Verbiest told another story about when perspective was first shown to the Chinese court, in which there were images with an architectural subject similar to the ones above. The Italian Jesuit Ludovico Buglio (1606-82) 'had the paintings composed from several books ... and had them delineated as large as possible'. These three very large paintings, one representing a Chinese palace, and the other two of a European palace and a garden, were 'excellently executed according to her own laws' around 1667. ${ }^{31}$ Buglio was in Beijing after 1648, and the three pictures are unknown to us. This story can be taken as the earliest record of European painting created with perspective that appeared in the Chinese court, and, as Verbiest commented, 'You can hardly believe how this art attracted everybody's attention'. ${ }^{32}$ Moreover, in two other chapters of the Astronomia Europaea - on optics and catoptrics - the Chinese fascination with the employment of European optical techniques, such as camera 
obscura, is the core issue as well. The Jesuit missionaries seem to have had a conscious awareness of this attraction on the part of the local people to the optical methods, such as perspective, and other optical equipment.

Therefore, the Chinese reaction to the advance of Western skills might have become an impetus for missionaries to introduce European paintings and other arts to China. A source of 1690 testifies to this, as the Jesuit Franciscus de Rougemont (1624-76) advised that the missionary residence be 'equipped, in view of a major success, with perspective paintings and all kinds of other curiosities'. ${ }^{33}$ That paintings of perspective are mentioned along with 'other curiosities' indicates that the art of perspective could gain success by means of a similar attraction to such things as 'curiosities'.

However, a series of Jesuit Chinese woodcuts based on a European model could challenge our usual interpretation of perspective as a missionary strategy in China, because there is a contradiction between two pictorial methods, in the way that perspective is employed, within the same work. The woodcut series entitled Tianzhu jiangsheng chu xiang jing jie 天主降 生出像經解 (Biblical Explanations and Illustrations of the Heavenly Lord's Incarnation, abbreviated Chu xiang jing jie; first edition 1637) was edited by the Jesuit Giulio Aleni (1582-1649) and published by a Catholic church of the County of Jinjiang (晉江景教堂), in the southeast coastal Province of Fujian (福建省). ${ }^{34}$ Due to its scope and the number of surviving copies and editions, this is the most important illustrated Chinese version of the Gospel in the seventeenth century. There are at least twenty-nine editions or copies extant. The Chu xiang jing jie is an intentionally faithful, yet indigenized duplicate of its European original, the illustrated Gospel Evangelicae Historiae Imagines (Images of Evangelical History, abbreviated Evangelical History) by the Jesuit Jerome Nadal (1507-1580), first published in Antwerp in 1593. The woodcuts retain the European format and composition, but the European copper engravings and language are replaced by Chinese versions. ${ }^{35}$ The Chu xiang jing jie include fifty to sixty prints in different editions, fewer than Nadal's whole set of 153 engravings. Nevertheless, this Chinese series of woodcuts is a self-sufficient work, with the Incarnation as its special focus. In this series, we find that one print entitled 'Cure of the Centurion's Servant' seems intentionally to avoid the forceful three-dimensional depiction of chiaroscuro and changes the representation of figures made visible by the same source of light, but we also see some interesting compositions that utilize European spatial arrangement in perspective. ${ }^{36}$ In contrast to their European models, four prints in Aleni's work show extra depictions of openings in the wall, and visual extension by the addition of a Chinese-landscape screen, so that the vision of the audience can penetrate through the two-dimensional plane. For example, in the print the 'Holy Sacrament', flanking the central two pilasters is a brick-and-tile wall, with a rectangular window on each side that opens to the outside cityscape and landscape, neither of which is seen in the European original (Figs. 1, 2). ${ }^{37}$ In the Renaissance tradition of perspective, 


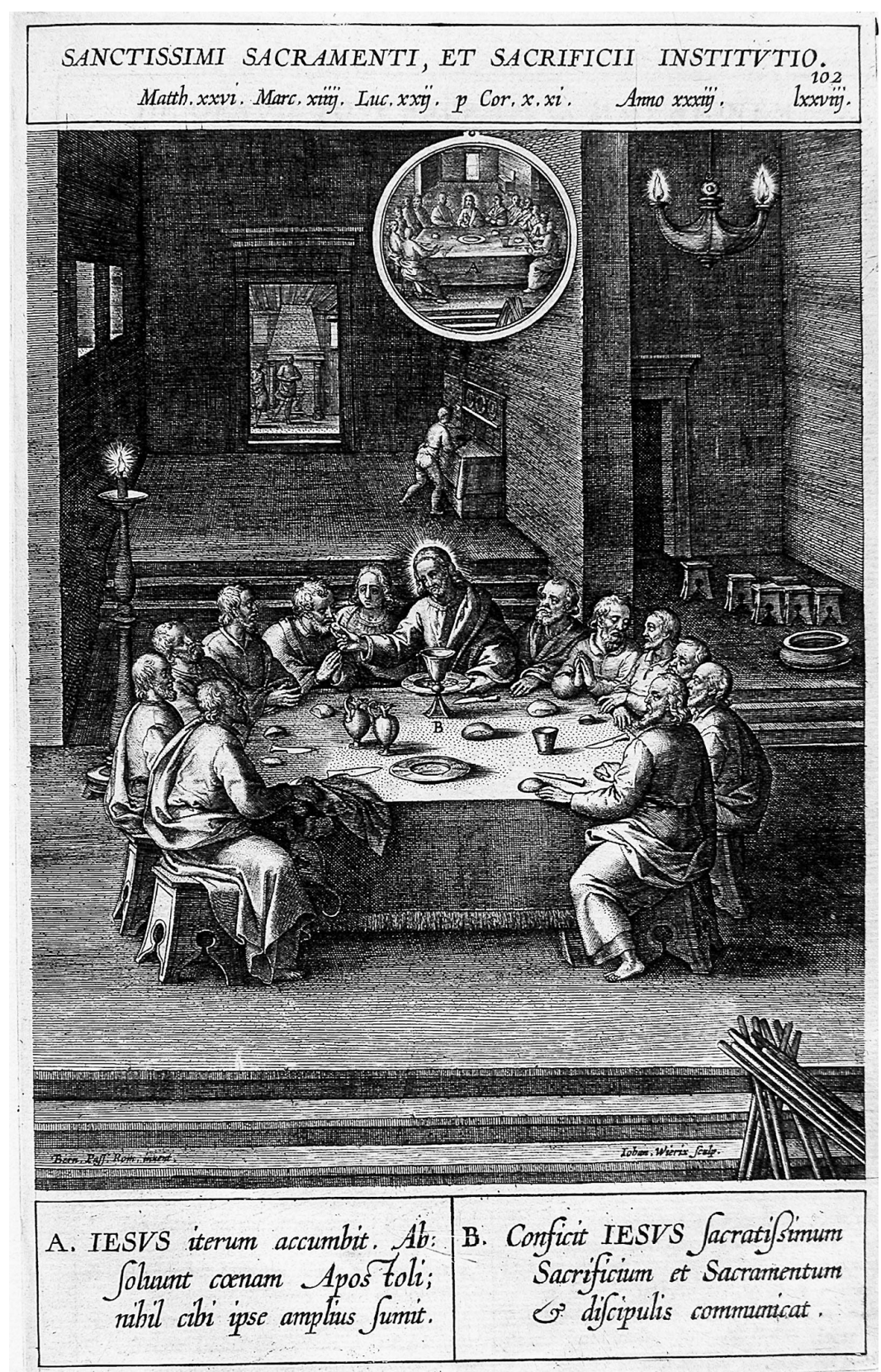

Figure 1 'The Holy Sacrament', no. 102, Jerome Nadal, Evangelicae Historiae Imagines (Images of Evangelical History) (1593), () Institutum Historicum Societatis Iesu, Rome, Italy 


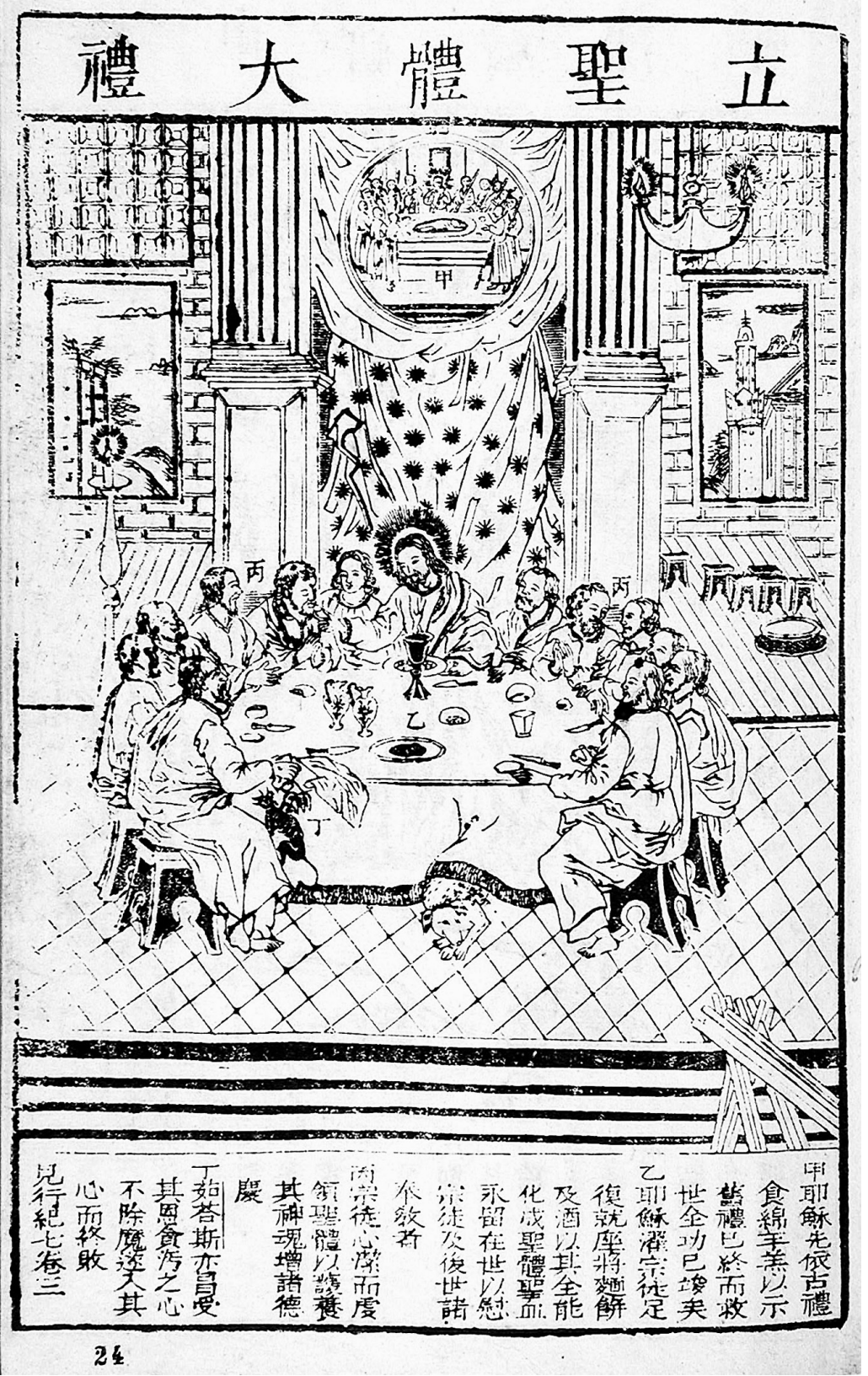

Figure 2 'The Holy Sacrament', from Giulio Aleni, Tianzhu jiangsheng chu xiang jing jie 天主降生出像經解 (Biblical Explanations and Illustrations of the Heavenly Lord's Incarnation, 1637), Jap.Sin. I 187, f. 24, ( Archivum Romanum Societatis Iesu, Rome, Italy 


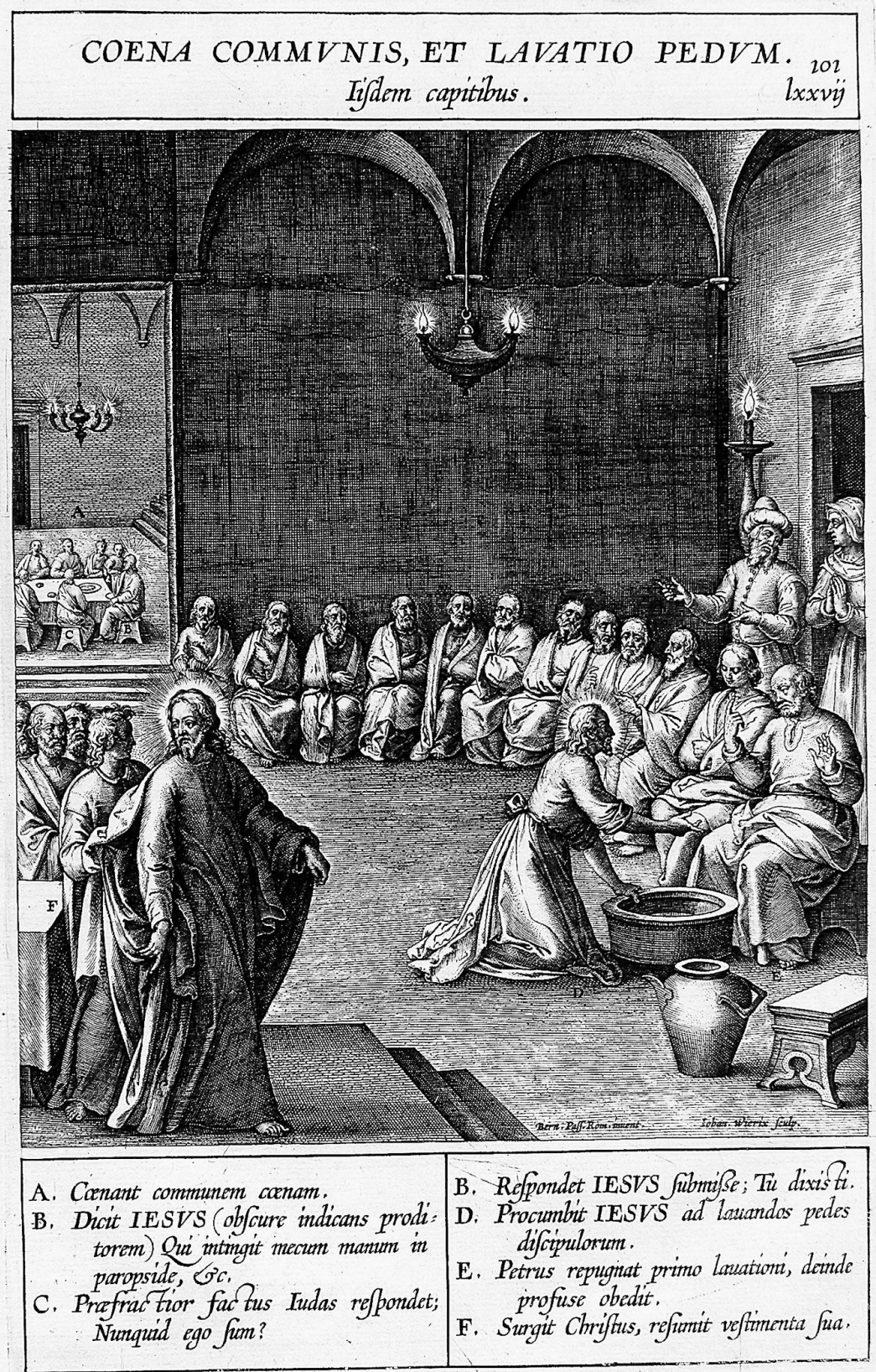

Figure 3 'Washing the Feet at the Last Supper', no. 101, Jerome Nadal, Evangelicae Historiae Imagines (Images of Evangelical History) (1593), (O Institutum Historicum Societatis Iesu, Rome, Italy 


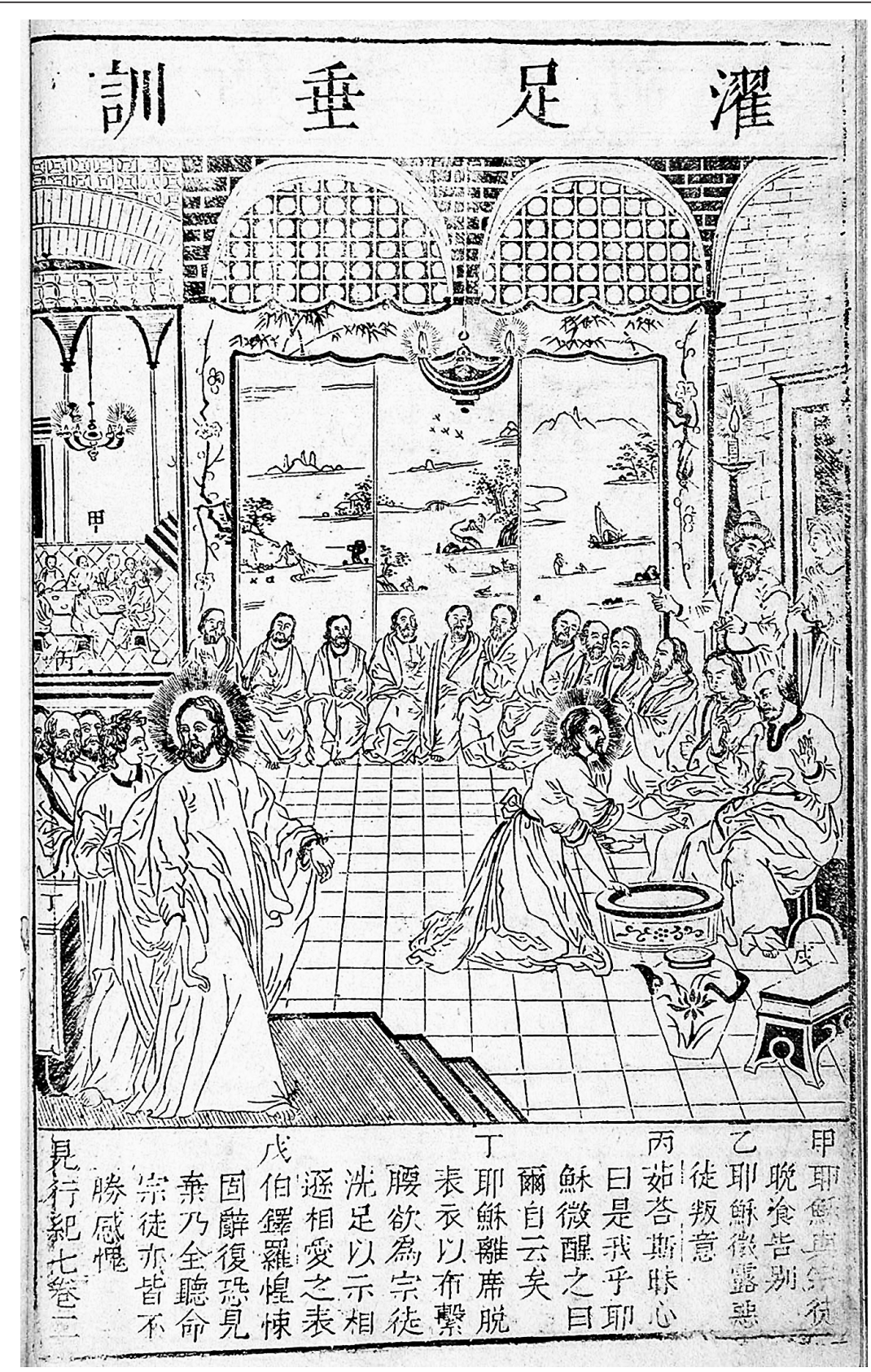

Figure 4 'Washing the Feet at the Last Supper', from Giulio Aleni, Tianzhu jiangsheng chu xiang jing jie 天主降生出像經解 (Biblical Explanations and Illustrations of the Heavenly Lord's Incarnation, 1637), Jap.Sin. I 187, f. 23v, () Archivum Romanum Societatis Iesu, Rome, Italy 
the painting surface is an 'open window', as Alberti states, 'through which [window] the subject to be painted is seen'. ${ }^{38}$ As Panofsky articulates, in the Renaissance convention, the entire picture is transformed into a window, so that we are looking through this 'window' into space. ${ }^{39}$ Breaking the wall surface is a strong claim to spatial 'conquest' on a pictorial plane, because the opening explains the potential depth. This alternation, by adding 'windows' to the Chinese prints, could be seen as a visual metaphor of Renaissance perspective. $^{40}$

Moreover, there are eight woodcuts in the Chu xiang jing jie that show a tiled floor instead of merely the plain one in their European models (Figs. 3, 4). ${ }^{41}$ The tiled floor indicates spatial depth in a descriptive way. It could be a localized result or preference, as is the style of the Chinese landscape beyond the openings and the brick wall, yet the purpose to extend or suggest the potentiality of space is self-evident. These differences between the Chinese version and the European original indicate an artistic appropriation, whether under Jesuit guidance or as the preference of the Chinese cutter, and in the case of the 'Cure of the Centurion's Servant', the appropriation could have been a purposeful one to delete the chiaroscuro effect. However, the extra openings and a tiled floor are used to emphasize the concept of perspective, as thought lacking in Chinese traditions. The missionary publication would intend to introduce a new pictorial method - perspective - or to adapt to an indigenous habit of visuality, both observed in the same work with a single editor (Aleni). We have deduced that perspective could have become an intentional tool of missionaries in terms of visual effect. However, chiaroscuro could have consciously been avoided in the Chinese version of a European image, since the European conventions of light-shadow-colour were a different way of viewing nature in China, to a shocking degree. Although we cannot further explain this contradiction in Aleni's series, this case illustrates for us the complications of a historical interpretation: perspective considered as a strategy can be a more difficult and complicated question than is usually thought.

There are two points of view to be proposed from the above discussion. First, the central factor of the Chinese responses to those Europeanstyle images indicates a perception on a technical level. At this level, the Chinese expressed their responses in a positive way. Second, except for the Western images showing secular buildings and gardens described in Verbiest's Astronomia Europaea, all other images of perspective that the Chinese viewed with admiration involve religious subjects. The Jesuit world maps in China also show implicitly a message of Christian doctrines. ${ }^{42}$ With regard to the first point, one especially important and conspicuous feature of the way the Chinese viewed Western images pertains to chiaroscuro in perspective, the use of light and the making of shadow. The visual effect generated by chiaroscuro is a kind of illusion. A scientific supposition is the prerequisite of Edgerton's argument, i.e., that perspectival European images offered to the 
Chinese a scientifically objective and realistic presentation. ${ }^{43}$ I would argue, instead, that the illusion of chiaroscuro should point us toward a psychological and anthropological view of this perception, rather than to a supposition of scientific objectivity. Before considering further the Chinese illusion and its possible connection to religious realms, we should look more closely at the position of perspective in the Jesuit context.

\section{Perspective in the Missionary Context}

Linear perspective was among the relevant fields that elevated the status of art in the intellectual hierarchy during the Renaissance period. In this intellectual context, the rational power of the imagination and the significance of the sense of vision, which were framed in the neo-Aristotelian theory of cognition, were vital to Renaissance arts in theorizing and intellectualizing the disciplines. ${ }^{44}$ Perspective was conceived in the Jesuit missions through the concept of scientia. The scientia of the Renaissance and seventeenth century should be understood by different historical criteria from the modern word 'science', which concerns technology and its objective observation of the world. ${ }^{45}$ Nicolas Standaert's research has attempted to recover 'the mental categories pertaining to science in the early contact between China and the West', which were incorporated into the Jesuit framework of education and knowledge and revealed in a Jesuit Chinese work entitled Ming li tan 名理 探 (On Philosophy), dating from 1631. ${ }^{46}$ The European model of the Ming li tan originated with a Jesuit pedagogical text used at the Jesuit College of Arts in Coimbra, Portugal, In Universam Dialecticam Aristotelis (1606). ${ }^{47}$ In this Jesuit system, 'science' can be seen as a general term similar to 'art', meant to cover grammar, rhetoric, physics, medicine, etc. For example, within one category of this classification, 'painting' is found under the heading 'external practical sciences'; and 'perspective', along with 'astronomy', under the heading 'quantitative theoretical sciences'. Moreover, early in the 1550s, perspective was a branch discipline of mathematical study, proposed around 1552 by the early important Jesuit Jerome Nadal and shown in the study plan of the Jesuit Collegio Romano (1558-60). ${ }^{48}$ In both of the important official documents, the Constitutions (1556) and later the normative instruction of Jesuit pedagogy, Ratio Atque Institutio Studiorum Societatis Iesu (known as the Ratio Studiorum, final version published in 1599), mathematics was indicated as a training discipline under 'philosophy'. ${ }^{49}$ The Ratio Studiorum became a standard curriculum of study in Jesuit educational institutes, not only in Europe but also in the overseas missions. A letter of the Jesuit Manuel Dias to General Claudio Aquaviva written in Macao on 12 November 1597 mentioned the use of the Ratio Studiorum for theological studies. ${ }^{50}$ However, except for Macao, the Jesuits were not able to institutionalize their educational ideas in any of the China missions, on account of several specific impediments 
in China. Since education was an important feature of the Jesuit missions and by means of this we examine the Jesuit global contribution to cultures - the China mission is a disappointing instance..$^{51}$ For centuries, the Jesuits in China have been praised as cultural emissaries between Europe and China, and yet their efforts, unlike other cases in Europe or the Americas, were never demonstrated through a systematic establishment of Jesuit education.

Although education may have failed in the China mission, Jesuit preaching and evangelical work were performed from their epistemological base, shown in pedagogical plans, and the missionaries also demonstrated the uses of several disciplines in this knowledge system. If mathematics was significant for the formation of Jesuit pedagogy in the sixteenth century, then it is not surprising to note that Euclid's geometry, arithmetic, geography and cosmography, perspective, and horology - those courses assigned for the Jesuit mathematical training - can all be found in the theoretical and material areas of the Jesuits for the China mission. They might have been used and shown, nonetheless, in a cultural engagement, instead of in a formal Jesuit educational system. As Christopher Chapple states, the Society of Jesus had a twofold mission: to educate and to evangelize. ${ }^{52}$ In the case of China, the Jesuit knowledge system was shown throughout their missionary aim of evangelization, not developed in the building of schools and in teaching.

The Jesuit use of science conformed to their educational system, which ultimately served to comprehend the law of Heaven, i.e., theology. As stated above, Diaz's letter of 1597 mentioned the use of the Ratio Studiorum for theological studies. Mathematics and astronomy were the basic training courses for Jesuit students and were seen as a necessary preparation for theological studies. ${ }^{53}$ Additionally, the documents of the 1550 s that have already been discussed along with the Ratio Studiorum all pointed to the final purpose of the study, which was directed towards theology. This European knowledge-system was called in Chinese xue 學 (studies) or xixue 西學 ('Western Studies') in Jesuit Chinese literature, and it also explains that Jesuit engagement in mathematical and astronomical knowledge should be understood within the larger Jesuit intellectual structure, the introduction of which was aimed at non-Christian converts for studying Heavenly doctrine - in Chinese tianxue 天學 (literally 'Heavenly Studies'). The first book-compilation of the 'Heavenly Studies', Tianxue chuban 天學初函 (1628), includes Giulio Aleni’s treatise entitled Xixue fan 西學凡 (Introduction to Western Studies) (1623). ${ }^{54}$ The 'Western Studies' were encompassed under the umbrella of the 'Heavenly Studies'.

Therefore, science and religion are not shown in opposition to one another, as in 'secular' versus 'sacred'. The use of science in the Jesuit mission was by nature associated, in the Jesuit mind, with their evangelization. Moreover, artistic perspective (usually known as perspectiva artificialis), like the linear perspective of the Renaissance, and mathematical perspective (perspectiva communis), were much more articulated at the time as practice versus theory, 
in principle, but later turned out to be more complicated. As the work of Elisabetta Corsi shows, the medieval tradition of perspective, or optics, continued into the Renaissance period. Even in the seventeenth century, the theory of vision was still very traditional, implicated with the notions of morality and spirituality. ${ }^{55}$ However, even though a Renaissance perspectival representation could have been analyzed both with a mathematical eye and with the theological implication of optics, it has been noted as well that artistic or visual perspective was not as scientifically measured as is generally thought. As J. V. Field observed with respect to early Renaissance works of art, 'So it had turned out that in practice the mathematical rules of perspective only needed to be applied in a rudimentary manner in order to achieve a satisfactory sense of depth. ${ }^{56}$ In the case of China, we find that the perspectiva artificialis reached some such results that actually do not depend on mathematical theory, and the response of the Chinese audience was not related to mathematical knowledge.

In addition, titles on perspective in several European languages which had been published in the second half of the sixteenth century are found in Beitang's 北堂 catalogue (see the List below). ${ }^{57}$ The most noted is that of Joannes Pisanus (ca. 1240-92) - that is, John Pecham's - Perspectiva communis, of which, there are three titles in the catalogue (nos. 1872-1874). As Edgerton stated, Pecham's Perspectiva was a very important source for Alberti's treatise on painting, which promoted the construction of linear perspective on a flat surface..$^{58}$ It has been established that Pecham's book enjoyed wide circulation in Europe, and its appearance in Beitang's catalogue confirms its popularity. Euclid's works have two titles in this collection (nos. 3265, 3785), and one of them is the translation of the mathematician Egnazio Danti (1537-86). Danti wrote a commentary on the architect Giacomo Barrozzi da Vignola's (1507-73) Le due regole della prospettiva (nos. 3530-31), which also appeared in Beitang's catalogue. Both were published together in 1583 and reprinted several times later. Furthermore, Field's research elaborated on the works by several mathematicians of the sixteenth century and their mutual relationships, among them Daniele Barbaro (1513-70), Guidobaldo del Monte (1545-1607), Giovanni Battista Benedetti (1530-90), and Simon Stevin (1548-1620). Their major works on perspective all happen to have been included in Beitang's catalogue (nos. 3162, 992, 1427-28, 660). As Field pointed out, these works indicated that the sixteenth-century mathematicians were engaged in perspective as 'regrafting perspectiva artificialis back onto its old stem of perspectiva communis'. ${ }^{59}$ The List below also shows that almost all the works brought to China were from the type of the perspectiva communis, done by mathematicians or engineers (such as Samuel Marolois, active in the first half of the seventeenth century), rather than by artists. The only exceptions are those of Vignola, the architect-painter-engraver Jan Vredeman de Vries (1527-1604), and the architect and artist Andrea Pozzo, S. J. (1642-1709)..$^{60}$ Although it is not known exactly how and when these European books on perspective came 
to China, and in what way they were used for the Jesuit missions, we refer back to their European contexts and can deduce that they might have been brought in with the intention of presenting 'perspective as mathematics'. In other words, housed as they were in the court, they could have been used mostly for Jesuit scientific projects.

\section{List}

Titles on Perspective Found in C. M. H. Verhaeren (ed.), Catalogue de la Bibliothèque du Pé-tang (1949; reprint, Paris, Belles Lettres, 1969)

* Listed chronologically by year, but grouped by author

\begin{tabular}{|c|c|c|c|c|}
\hline $\begin{array}{l}\text { Catalogue } \\
\text { No. }\end{array}$ & Author & Title & Publisher & Year \\
\hline 1872 & $\begin{array}{l}\text { Pisanus } \\
\text { Joannes (ca. } \\
\text { 1240-92) }\end{array}$ & $\begin{array}{l}\text { Perspectiva communis. Ideo } \\
\text { sic dicta, quod contineat } \\
\text { elementa... }\end{array}$ & $\begin{array}{l}\text { Norimbergae, } \\
\text { Apud Johan. } \\
\text { Petreium }\end{array}$ & 1542 \\
\hline 1873 & - & $\begin{array}{l}\text { Perspectiva tribus libris } \\
\text { succinctis denvo correcta, et } \\
\text { figuris illustrata, per Pasca- } \\
\text { sium Hamellium mathema- } \\
\text { ticum Regium }\end{array}$ & $\begin{array}{l}\text { Lvtetiae, Apud } \\
\text { Aegidium } \\
\text { Gourbinum }\end{array}$ & 1556 \\
\hline 1874 & - & $\begin{array}{l}\text { (Ioannis Archiepiscopi } \\
\text { Cantvariensis) Perspectivae } \\
\text { communis libri tres. Iam } \\
\text { postremo correcti ac figuris } \\
\text { illustrate }\end{array}$ & $\begin{array}{l}\text { Coloniae Agrip- } \\
\text { pinae, Apud } \\
\text { Haeredes Arnoldi } \\
\text { Birckmanni }\end{array}$ & 1580 \\
\hline 3162 & $\begin{array}{l}\text { Barbaro, } \\
\text { Daniele } \\
(1513-70)\end{array}$ & $\begin{array}{l}\text { La pratica della perspet- } \\
\text { tiva di Monsignor Daniel } \\
\text { Barbaro eletto patriarcha } \\
\text { d'Aquileia.... }\end{array}$ & $\begin{array}{l}\text { Venetia, Appresso } \\
\text { Camillo, \& } \\
\text { Rutilio Borgami- } \\
\text { nieri fratelli }\end{array}$ & 1569 \\
\hline 3946 & $\begin{array}{l}\text { Lencker, Hans } \\
\text { (d. 1585) }\end{array}$ & $\begin{array}{l}\text { Perspectiva Hierinnenn } \\
\text { auffs kurtzte beschrieben.... }\end{array}$ & $\begin{array}{l}\text { Nüremberg, } \\
\text { durch Dietrich } \\
\text { Gerlatz }\end{array}$ & 1571 \\
\hline 3185 & $\begin{array}{l}\text { Bassi, Martino } \\
\text { (fl. 16th c.l; } \\
\text { Milanese) }\end{array}$ & $\begin{array}{l}\text { Dispareri in materia } \\
\text { d'architettura, et perspet- } \\
\text { tiva, Con pareri di eccellenti, } \\
\text { et Famosi Architetti, che li } \\
\text { risoluono }\end{array}$ & $\begin{array}{l}\text { Bressa, Per } \\
\text { Francesco, \& Pie. } \\
\text { Maria Marchetti } \\
\text { Fratelli }\end{array}$ & 1572 \\
\hline 3265 & $\begin{array}{l}\text { Euclides (3rd } \\
\text { c. B.C.) }\end{array}$ & $\begin{array}{l}\text { La Prospettiva di } \\
\text { Euclide...Tradotta dal } \\
\text { R. P. M. Egnatio Danti } \\
\text { Cosmografo del Seren. Gran } \\
\text { Duca di Toscana }\end{array}$ & $\begin{array}{l}\text { Fiorenza, Nella } \\
\text { Stamperia de' } \\
\text { Giunti }\end{array}$ & 1573 \\
\hline
\end{tabular}




\begin{tabular}{|c|c|c|c|c|}
\hline 785 & - & $\begin{array}{l}\text { La perspectiva y especularia } \\
\text { de Euclides. Traduzidas en } \\
\text { vulgar Castellano, y dirig- } \\
\text { idas a la S. C. R. M. del Rey } \\
\text { don Phelippe nuestro Senor }\end{array}$ & $\begin{array}{l}\text { Madrid, En casa } \\
\text { de la viuda de } \\
\text { Alonso Gomez }\end{array}$ & 1585 \\
\hline 92 & $\begin{array}{l}\text { Benedetti, } \\
\text { Giambattista } \\
(1530-1590)\end{array}$ & $\begin{array}{l}\text { (Io. Baptistae Benedicti } \\
\text { Patritij Veneti Philosophi) } \\
\text { Diversarum speculationum } \\
\text { Mathematicarum, E } \\
\text { Physicarum Liber.... } \\
\text { Among the contents: De } \\
\text { rationibus operationum } \\
\text { perspectivae }\end{array}$ & $\begin{array}{l}\text { Taurini, Apud } \\
\text { Haeredem } \\
\text { Nicolai Beuila- } \\
\text { quae }\end{array}$ & $\begin{array}{r}1585 \\
(1 s t \\
\text { edn } \\
1580)\end{array}$ \\
\hline $427-28$ & $\begin{array}{l}\text { Del Monte, } \\
\text { Giudobaldo } \\
(1545-1607)\end{array}$ & Perspectivae libri sex & $\begin{array}{l}\text { Pisavri, Apud } \\
\text { Hieronymum } \\
\text { Concordiam }\end{array}$ & 1600 \\
\hline 60 & $\begin{array}{l}\text { Stevin, Simon } \\
(1548-1620)\end{array}$ & $\begin{array}{l}\text { Memoires mathematiques, } \\
\text { Contenant de en quoy s'est } \\
\text { exercé le tres-illustre, tres- } \\
\text { excellent Prince É Seigneur } \\
\text { Maurice Prince d'Orange.... } \\
\text { Pt. 3: Des perspectives }\end{array}$ & $\begin{array}{l}\text { Leiden, Chez Ian } \\
\text { Paedts Iacobsz }\end{array}$ & 1608 \\
\hline 530 & $\begin{array}{l}\text { Vignola, } \\
\text { Giacomo } \\
\text { Barrozzi da } \\
(1507-73)\end{array}$ & $\begin{array}{l}\text { Le due regole della prospet- } \\
\text { tiva pratica di M. Iacomo } \\
\text { Barozzi da Vignola Con } \\
\text { i comentarii del } R . P . M \text {. } \\
\text { Egnatio Danti dell' ordine } \\
\text { de Predicatori... }\end{array}$ & $\begin{array}{l}\text { Roma, Nella } \\
\text { Stamperia della } \\
\text { Reueren. Camera } \\
\text { Apostolica }\end{array}$ & $\begin{array}{r}1611 \\
(1 s t \\
\text { edn } \\
1583)\end{array}$ \\
\hline 531 & - & - & $\begin{array}{l}\text { Roma, Per il } \\
\text { Mascardi }\end{array}$ & 1684 \\
\hline 903 & Brunn, Lucas & $\begin{array}{l}\text { Praxis perspectivae Das ist: } \\
\text { Von Verzeichnungen ein } \\
\text { aussfübrlicher Bericht... }\end{array}$ & $\begin{array}{l}\text { Nüremberg, } \\
\text { Bey Simon } \\
\text { Halbmeyer. } \\
\text { Vnd Gedruckt } \\
\text { zu Leipzig Bey } \\
\text { Lorentz Kober }\end{array}$ & 1615 \\
\hline 193 & $\begin{array}{l}\text { Marolois, } \\
\text { Samuel (1st } \\
\text { half of the } \\
17 \text { th c.) }\end{array}$ & $\begin{array}{l}\text { Opticae Sive Perspectivae, } \\
\text { pars prima [-quarta]: conti- } \\
\text { nens Praeter regulas ac } \\
\text { demonstrationes Opticae } \\
\text { perfectissimas, Geometriae, } \\
\text { Fortificationis, E praesertim } \\
\text { Architecturae figuras } \\
\text { accuratas... }\end{array}$ & $\begin{array}{l}\text { Amstelodami, } \\
\text { Sumptibus ac } \\
\text { typis Ioannis } \\
\text { Ianssonii }\end{array}$ & 1633 \\
\hline
\end{tabular}




\begin{tabular}{|c|c|c|c|c|}
\hline 3075 & $\begin{array}{l}\text { Vredeman } \\
\text { de Vries, Jan } \\
(1527-1604)\end{array}$ & $\begin{array}{l}\text { Perspectiva theoretica ac } \\
\text { practica. Hoc est, Opus } \\
\text { opticum absolutissimum.... }\end{array}$ & $\begin{array}{l}\text { Amstelodami, } \\
\text { Sumptibus ac } \\
\text { typis Ioannis } \\
\text { Ianssonii }\end{array}$ & $\begin{array}{l}1633 \\
(1 \mathrm{st} \text { ed. } \\
1604-5)\end{array}$ \\
\hline 2328 & $\begin{array}{l}\text { Niceron, } \\
\text { Jean François } \\
(1613-46)\end{array}$ & $\begin{array}{l}\text { (R. P. Ioannis Francisci } \\
\text { Niceronis Parisini, ex Ord. } \\
\text { Minim.) Thaumaturgus } \\
\text { opticus seu Admiranda } \\
\text { optices, per radium } \\
\text { directum...In quibus praeter } \\
\text { Scenographiae seu Perspec- } \\
\text { tivae communis funda- } \\
\text { menta.... }\end{array}$ & $\begin{array}{l}\text { Lvtetiae } \\
\text { Parisiorum, } \\
\text { Typis \& formis } \\
\text { Francisci } \\
\text { Langlois, aliàs } \\
\text { dicti Chartres }\end{array}$ & 1646 \\
\hline 507 & - & $\begin{array}{l}\text { La perspective curieuse } \\
\text { du Reverend P. Niceron } \\
\text { Minime, divisée en quatre } \\
\text { livres }\end{array}$ & $\begin{array}{l}\text { Paris, Chez lean } \\
\text { du Puis }\end{array}$ & $\begin{array}{c}1663 \\
(1 \mathrm{st} \text { ed. } \\
1638)\end{array}$ \\
\hline 2163 & $\begin{array}{l}\text { Maignan, } \\
\text { Emmanuel } \\
(1601-76)\end{array}$ & $\begin{array}{l}\text { Perspectivae horaria: sive. } \\
\text { De horographia gnomonica } \\
\text { tum theoretica, tum practica } \\
\text { libri quator... }\end{array}$ & $\begin{array}{l}\text { Romae, Typis \& } \\
\text { Expensis Philippi } \\
\text { Rubei }\end{array}$ & 1648 \\
\hline 2511 & $\begin{array}{l}\text { Pozzo, } \\
\text { Andrea, S.J. } \\
(1642-1709)\end{array}$ & $\begin{array}{l}\text { Perspectiva pictorum et } \\
\text { architectorum Andreae Putei } \\
\text { e Societate Jesu.... }\end{array}$ & $\begin{array}{l}\text { Romae, Ex } \\
\text { Typographia } \\
\text { Antonii de } \\
\text { Rubeis }\end{array}$ & $\begin{array}{c}1702- \\
23\end{array}$ \\
\hline 2512 & - & $\begin{array}{l}\text { Perspectiva pictorum atque } \\
\text { architectorum I [-II] } \\
\text { Pars... Quâ facillima ac } \\
\text { expeditissima Methodus } \\
\text { omne id quod ad Archi- } \\
\text { tecturam attinet, optica } \\
\text { ratione delineandi exhibetur, } \\
\text { inventa, designata et } \\
\text { primum edita Romae a Fr. } \\
\text { Andrea Puteo S. J..... }\end{array}$ & $\begin{array}{l}\text { Augustae Vinde- } \\
\text { licorum, Impensis } \\
\text { Jeremiae Wolffi } \\
\text { Techniopolae }\end{array}$ & $\begin{array}{c}1706- \\
19\end{array}$ \\
\hline 380 & $\begin{array}{l}\text { La Caille, } \\
\text { Nicolas Louis } \\
\text { de (1713-62) }\end{array}$ & $\begin{array}{l}\text { Leçons elementaires } \\
\text { d'optique. Par M. l'Abbé de } \\
\text { la Caille.... }\end{array}$ & $\begin{array}{l}\text { Paris, Chez H. L. } \\
\text { Guerin \& L. F. } \\
\text { Delatour }\end{array}$ & 1764 \\
\hline
\end{tabular}

\section{Chinese Perception: Complexity of Illusion and Reality}

From the point of view of the Chinese reaction to European perspective, the visual effect generated by chiaroscuro is a kind of 'illusion'. The Chinese were fascinated by the illusionary result of this Western skill, in part because 
the visual representation of light and shadow presented a different way of viewing of nature from their own. As we note in the Renaissance context, with regard to light and colour, Alberti stated as follows:

It is evident that colours vary according to light, as every colour appears different when in shade and when placed under rays of light ... Philosophers say that nothing is visible that is not endowed with light and colour. There is, then, a very close relationship between colours and lights in the function of sight. ${ }^{61}$

Pecham's Perspectiva communis also acknowledges the important roles light and colour play in optics. ${ }^{62}$ In addition to Pecham's work, in the Beitang List above, the works by Daniele Barbaro and Guidobaldo del Monte on this topic also show a particular interest in chiaroscuro. ${ }^{63}$ One Jesuit Chinese work, Aleni's Xingxue cushu 性學觕述 (On Human Nature; Aleni's preface dated 1623) says that the sense of sight lies in the realm of the perception of colours and light. This statement conforms to Alberti's thesis:

目為五官之尊, 以視為職, 其德在明, 其視之界, 為色, 為光。

Eyes are the highest among the five organs of the senses. The duty of the eyes is the sight, and their merit lies in illumination. The realm of vision is colours and light. ${ }^{64}$

Chinese pictorial traditions never recognized such a light-shadow theory; thus there should be a fundamental discrepancy between the West and the Chinese in questions of what one sees in nature and in pictures, and of the visibility of those things depicted in a painting. The late-Ming pictorial traditions relied, instead, on the calligraphic brushstroke; as Dong said, 'the renderings of convexity and concavity should be immediately perceived upon the falling of a brush on panel (下筆便有凹凸之形)'. However, it is this very style that was criticized by Ricci as lacking colour and shade. ${ }^{65}$

As discussed above, the majority of the images shown using perspective that the Chinese admired in the seventeenth century involve religious subjects. There is a rare story in Chinese sources stating the connection between the Western pictorial skills and their religious effect. A Chinese account of 1643 describes atypically a Western artist who painted an image of 'Cundī' (準提 像) in the Western style, which was highly admired:

大西洋琍瑪䆩所攜諸畫像, 俱蠟地重著色, 人物儼映冰壼, 閒是六法別傳異 派。今西士在漳南者, 以此為生涯矣。…余更有準提像, 則紙上設色, 不但妙 相莊嚴, 抑亦寶光煥發, 雖吳道子運筆, 諒莫能過, 允宜冠亞墨利加也。

Several pictures that Matteo Ricci of the Western Ocean brought with him are all in oil, emphasizing the uses of colours. Figures depicted [in Ricci's paintings] look like reflections on an icy bottle [as they appear in reality], and this is a different style or school than that of the Six Schools [in Chinese artistic traditions]. Nowadays, a Western person who is living in the southern Prefecture of Zhangzhou carries on this profession ... [Among his or her paintings] there is an image of 'Cundì', 
coloured on paper. The appearance is not only wonderful and dignified, but also bright and irradiated with precious light. Even the brush of Wu Daozi cannot exceed it. The painter should top America. ${ }^{66}$

This description shows that the pictures Ricci brought with him impressed certain Chinese people, and the critique of the coloured, Western-style painting indicates that this style differs from local traditions. The 'Cundī' is a bodhisattva in esoteric Buddhism to which the iconography of Guanyin was related. Although the Western painter is unknown to us, the pictorial superiority of the Western religious subject gained such praise that some people even thought of its overthrowing the work of the greatest figure painter in China, Wu Daozi (Tang Dynasty, c. 618-907). Michael Sullivan pointed out that the four Chinese characters used for the transliteration of the word 'America' are the same as those found in Ricci's and Verbiest's map. ${ }^{67}$ If placing Zhangnan in the southern Prefecture of Zhangzhou, in Fujian, is correct, it seems not to be out of the question that a painter of American origin could have worked there, since the close contact of this coastal province with Macao and Manila gave access to the channels of transport between the mainland and the New World. Moreover, the Western painter worked as a professional artist, which means that the selling of works of art offered a livelihood for the artist. In Chinese traditions, the professional is always ranked below the amateur. This account also explains the Chinese attraction to the effects of light in Western style, with a particular emphasis on colours, and again, the positive view of this perception was established by its technical performance.

This high commendation of Western coloured painting is centred on religious figural subjects, and the key point of praise lies in the sense of the 'real' that is achieved by Western pictorial skill. This judgment conforms to $\mathrm{Gu}$ Qiyuan's remark and that of several others, as mentioned above. Additionally, Ricci presented to the Wanli Emperor two images of the Virgin with Child, and the emperor responded to Western paintings, spontaneously and identically, on a technical level. Confronted with the foreign sacred images offered by the missionary, the emperor remarked acutely, 'questo è Dio vivo', which reveals the profound visual effect on Chinese sensibilities. ${ }^{68}$ As, or perhaps because, the Chinese people did not know Christian doctrine and iconography, all of the Chinese responses referred to above highlight the technical achievement rather than the sacred content. The Chinese illusion, instead, showed that the Chinese viewer may have been involved in a pictorial distinction which directed that distinction towards a perception of the duality of 'representation' and 'true-presence' with respect to the sacred image. When the depiction created an illusion such that the viewer believed that what he or she saw was real, then the Jesuits had achieved their desired effect of having non-Christians believe in the 'true-presence' embedded in Christian representations. As the Jesuit Rodrigo de Figueiredo said to Chinese Christian followers in 1627, the one 'whom the image of the Lord of Heaven depicted, the Creator of all, 
not a pagode, nor an idol, [was] but the true and living God'. ${ }^{69}$ The illusory effect of Western sacred images on the Chinese perceiving them could have been a symbolic reconciliation to the doctrine and contents of Christianity.

Here, illusion and reality are, thus, a complex. The apparent reality generated by an illusory view of a two-dimensional representation is a believable one inside its religious realms. For missionaries, the symbolic reconciliation could be promoted for the reason that the thing to be believed points to a supernatural sphere. The responses to perspective in the seventeenth-century Jesuit China mission exemplify Panofsky's theory of 'perspective as symbolic form', which is also the title of his highly regarded booklet. Reality for the Chinese viewers of Christian images rendered with Western chiaroscuro is 'the actual subjective optical impression', a psycho-physiological perception, which is different from an unchanged and homogeneous construction formed by the rationalization of perspective. ${ }^{70}$ The Chinese reading of perspectival images was carried out without an understanding of the mathematical background. The establishment of this psycho-physiological, perspectival view of space bears a profound significance, as attested by Panofsky, that 'perspective opens art to the realm of the psychological, in the highest sense, where the miraculous finds its last refuge in the soul of the human being represented in the work of art'. The illusion of the Western Christian figural pictures provoked a kind of 'miraculous' revelation for the Chinese when they found the depicted figures to be alive, so to say, since 'perspective, in transforming the ousia (reality) into the phainomenon (appearance), seems to reduce the divine to a mere subject matter for human consciousness; but for that very reason, conversely, it expands human consciousness into a vessel for the divine'. ${ }^{71}$ Panofsky's subtle theory of perspective as symbolic form enables us to gain insight into the Jesuit uses of perspectival visual materials and their possible stratagem for religious conversion.

Furthermore, the above account of 1643 states the effect of 'light' on perspective for the religious subject. For the missionaries, light is symbolic in Christian thought. The thirteenth-century optician and Franciscan friar Roger Bacon (1220-1292) wrote:

Since the infusion of grace is very clearly illustrated through the multiplication of light, it is in every way expedient that through the corporeal multiplication of light there should be manifested to us the properties of grace in the good, and the rejection of it in the wicked. ${ }^{72}$

Bacon's statement indicates that God's grace is manifested in light, and the physical study of light can direct one to the nature of God. As Edgerton points out, Robert Grosseteste (c. 1168-1253), another English Franciscan friar, explained even earlier that light was 'synonymous with God's grace', because, as created by God, it became 'the basic force for the divine energizing of the universe'. ${ }^{73}$ The Jesuit saint Peter Canisius (1521-97) elucidates the symbolic meaning of light while explaining the function of candles burning 
before sacred relics and images:

there $[s i c]$ cannot be founde or conceived, anye either more excellent or more fitte, than the ornament of lightes, or Candells. The first thing which God made was light. Light is a qualitie which bewtifieth all things, and of nothing can de defiled: it is so nere unto a spiritual nature, that it is only amongst all divisible accidents produced in a moment. ${ }^{74}$

Later, a Jesuit noted in an annual letter that the newly-founded church in the Province of Jiangxi (江西省), surrounded with two rows of windows in the Western style, was distinguished from the dark Chinese temple. ${ }^{75}$ Accordingly, light is a symbol of a new setting for a new religion. The positive response on the part of the Chinese to the visual effect of light could just have matched the missionary expectation of its religious implications.

On the other hand, as discussed above, whether perspective could have been considered as a strategy is a more difficult and complicated question than is usually thought. We also found that late-Ming society might have engaged in the interplay of illusion and reality, and of space and surface, in terms of visualization. ${ }^{76}$ It is in all likelihood that perspective could have just fitted into this cultural milieu. The key point regarding illusion lies not so much in terms of scientific objectivity or realistic presentation as in the power of visualization. As Corsi argues, the mathematic principle of perspective would not be rigidly applied when the effect of illusion was actually operating, as was seen already in the visual discourse of the Renaissance period. ${ }^{77}$ This coincides with Field's argument for Piero della Francesca's treatment (c. 1416-92) of perspectival construction, in which this construction was merely used as a prospective, having very little to do with mathematical science. ${ }^{78}$ As discussed above, a satisfactory depth achieved its visual effect without the viewer's knowledge or articulation of perspective communis in the China mission. Additionally, the skill in foreshortening of the fifteenthcentury painter Andrea Mantegna (1431-1506) illustrates a principle of 'perceptual psychology', as Michael Kubovy argues; the tolerance, that is, of visual inconsistency by the human mind. By analyzing Mantegna's work Dead Christ (1501), Kubovy points out two different vantage points of the painting, which shows a completely different working method from those of the theory of perspective as explained by Alberti. This artistic practice, diverging from the presumed mathematical principle, was quite common during the period of the Renaissance. ${ }^{79}$ This case tells us that the perception of the viewer could determine the effect caused by the actual distortion in the Dead Christ, if it were analyzed by the mathematical theory - which was modified by the sight and mind of the viewer. In my case, illusion indicates a perceptual psychology, by which the perception of the content of the subject by human sense became feasible: i.e., perception was changed from illusion to reality. Because of the psychological process, the theory behind the skill itself (perspective) could have been not so important. The seventeenth- 
century Jesuit Jean Dubreuil (1602-70) has already indicated as much in a similar remark with respect to the Jesuit China missions:

If you would like to proceed immediately to the Practice of Perspective without engaging in the intricacies of the Theory, the Jesuit's Perspective will answer your purpose. $^{80}$

Besides, the technical level of the Chinese reading of perspective explains another cross-cultural context regarding reality. When the Jesuit Johann Adam Schall von Bell (1591-1666) introduced the telescope in his treatise Yuan jing shuo遠鏡說 (On the Telescope) (1626), he also explained two methods that use the telescope inside a room to illustrate objects exactly as they should be transcribed on to canvas, a technique that had been used by European painters and craftsmen. The aim of these methods is to reflect the object in reality, so that it can be transferred exactly to a pictorial medium. ${ }^{81}$ This account shows that the Jesuits wanted to introduce these methods in a fashion similar to the Chinese impression of perspective, i.e., the depicted objects are to be made to look real. In terms of Jesuit scientific discourse in China, European technology was often praised because of its advanced capacity and effect. A passage found in a collaborative work of two Chinese Christians (1647) explains this aspect of Jesuit science:

\section{并所製便用省力諸器，測天諸儀、自鳴鐘、望遠鏡、各圖像画法等項，凡上天 下地, 宇宙萬彙, 無不推測諸所以然之理....然此等學問, 西士皆目為餘學耳, 惟所傳天學教法, 則為喫緊之要學。今相較論, 餘學種種, 既有實據如此, 則 其所謂喫緊之要學，豈不更有實理，愈有實據哉？}

Furthermore, various instruments [made by the missionaries] for saving energy and convenient uses, those for calculating the heavens, mechanical clocks, the telescope, several methods of depicting images and objects, etc., for all of the things in the sky and down on earth, and the multitude of things in the universe, they [the Jesuits] are all dedicated to the calculation and deduction of the principles of those things [by means of the above instruments] ... However, the missionaries simply considered these disciplines as incidental, or as branches, since only the teaching of Heavenly doctrines that they convey are significant and vital. By comparison, several disciplines of the incidental knowledge [sciences] prove to rest on such solid foundations, so the significant and vital studies [the teaching of Heavenly doctrines] should be based on more sound principles and rest upon even more substantial grounds. ${ }^{82}$

This remark is addressed from the angle of the hierarchy of the Jesuit 'Heavenly Studies' and their scientia, but it also indicates how the Chinese appreciated Jesuit scientific work - including pictorial methods - and commended its substantiation. To use the terms of Willard Peterson, the ideas found in Jesuit sciences merited practicability and employability, which was almost the main reason several Chinese literati and intellectuals in the seventeenth century were attracted to them. ${ }^{83}$ During the transition between the Ming and Qing dynasties, the Chinese people longed for pragmatism in study and thought, 
in contrast to the on-going confusion and emptiness they were experiencing in politics and society. Moreover, Benjamin Elman has argued that the Jesuit introduction of Western exact sciences could have significantly encouraged the tendency to evidential research, initiating during the late Ming, to prosper in the early Qing period. ${ }^{84}$

Nevertheless, it is precisely the technological point of view with regard to European perspective that would be condemned in Chinese artistic discourse. To use Cahill's term, the failure of perspective in Chinese art is 'a rejection of empirical method': the technological advance of perspective in the material sense reached a formal and scientific resemblance that was never the goal of Chinese artists. ${ }^{85}$ When perspective was understood merely from a material and technical point of view, it was not supposed to be able to converse in tandem with Chinese artistic traditions. The Chinese tradition of portraiture paid attention to the physical depiction and exactitude of figures; yet the key purpose was not physical but spiritual. ${ }^{86}$ The attainment of verisimilitude by perspective, as Chinese responses show, is only seen as a technical achievement in the eyes of Chinese artists. The intuitive and subjective realms that Chinese painting emphatically sought indicates a completely different aspect of artistic depiction; as Wen Fong observes, 'Western pictorial representation was directed at once toward the conquest of realistic appearance ... Pictorial representation for the Chinese, on the other hand, attempts to create neither realism nor ideal form alone. ${ }^{977}$ Dong's statement on the pictorial representation of landscape, and of landscape in nature, as quoted at the beginning of this paper, corresponds with that of Fong. Or, as E. H. Gombrich asserts, painting as a science represents 'experimentation' in the Western tradition, and this involves a psychological problem as the painter deals individually with the way to conjure up a convincing image that is based upon the nature of the individual's reactions to the physical world. ${ }^{88}$ Chinese pictorial traditions entailed another psychology, or 'mental set', to attain its human expression. ${ }^{89}$ The different categorizations of perspective in China and Europe show how the Chinese kept art and science in two separate discourses. From this angle, the praise of vividness and verisimilitude brought about by perspective could simply reflect fantasy and curiosity towards this foreign mode of representation on the part of Chinese viewers responding to it.

National Taiwan University

HUI-HUNG CHEN

\section{Notes}

The final version of this paper was revised according to the constructive and detailed comments of the reviewer. I express my deep gratitude for them. I would also like to express my deepest gratitude to Professor Elisabetta Corsi, for generously offering 
a copy of her article to me in person, and for her sincere and insightful discussions about the subject with me and several important suggestions about the bibliography. The research for this paper is derived from my dissertation, 'Encounters in Peoples, Religions, and Sciences: Jesuit Visual Culture in Seventeenth Century China' (PhD dissertation, Brown University, 2004). I would also like to express gratitude to my adviser, Professor Jeffrey Muller, for his advice on the original research, and to Professor Pingyi Chu, a research fellow of the Institute of History and Philology at the Academia Sinica, Taiwan, the adviser of my postdoctoral project, as its main writing was carried out while I was a postdoctoral fellow at the Academia Sinica.

This work and the publication are supported in part by National Taiwan University of Taiwan under Grant No. 95R0033-4.

1 James Cahill, The Compelling Images - Nature and Style in Seventeenth-Century Chinese Painting (Cambridge, Mass., Harvard University Press, 1982), pp. 4-5. The original Chinese text is as follows: '以徑之奇恠論, 則畫不如山水, 以筆墨 之精妙論, 則山水決不如畫。' It was taken from Dong Qichang 董其昌, Hua Zhi 畫旨 (The Intention of Painting), collected in his work entitled Rong tai bie ji 容臺別集, a 1630 edition of which was reprinted in Siku jinhuishu congkan 四庫 禁燬書叢刊, vol. 32 of Jibu 集部 (Beijing, Beijing chubanshe 北京出版社, 2000), p. $4 \mathrm{v}$.

2 On Painting: Leon Battista Alberti, trans. Cecil Grayson (London, Phaidon Press, 1972), pp. 37, 77 (for all three above quotations).

3 The quotation is taken from Samuel Y. Edgerton, Jr, The Renaissance Rediscovery of Linear Perspective (New York, Basic Books, Inc., 1975), p. 5.

4 Martin Kemp (ed.), Leonardo on Painting (New Haven, Yale University Press, 1989), p. 14.

5 For a history of the evolution of perspective, and the interrelation of art and science during the Renaissance period, see Edgerton, The Renaissance Rediscovery; Samuel Y. Edgerton, Jr, 'Galileo, Florentine "Disegno", and of the "Strange Spottednesse" of the Moon', Art Journal, 44 (Fall 1984), 225-32; Martin Kemp, The Science of Art: Optical Themes in Western Art from Brunelleschi to Seurat (New Haven, Yale University Press, 1990). Two special issues, Summer and Fall, of Volume 44 of Art Journal (1984), are dedicated to the topic of 'Art and Science' and edited by Edgerton. Michael S. Mahoney's criticism of Edgerton's emphasis on the essential relationship of art and science in terms of scientific diagrams is thoughtful in articulating the complexities of this matter, 'Diagrams and Dynamics: Mathematical Perspective on Edgerton's Thesis', in Science and the Arts in the Renaissance, ed. John W. Shirley and F. David Hoeniger (Washington, D.C., Folger Shakespeare Library, 1985), pp. 198-220. One basic point Mahoney counter-argues is that the Renaissance pictorial representation of machines did not explain a role of the arts necessary to the conceptual evolution of the sciences, as Edgerton claimed. As for examples from the seventeenth century, for the scientist Johann Kepler, see Svetlana Alpers, The Art of Describing: Dutch Art in the Seventeenth Century (Chicago, University of Chicago Press, 1983), pp. 26-71, and Anthony Grafton, Defenders of the Text: The Traditions of Scholarship in an Age of Science, 1450-1800 (Cambridge, Mass., Harvard University Press, 1991), pp. 178-203.

6 Kemp, Leonardo on Painting, p. 13.

7 Ibid., p. 14. 
8 Dong Qichang, Hua cha'n shi sui bi 畫禪室隨筆, in Biji xiaoshuo daguan 筆記小 說大觀, vol. 22:5 (Taipei, Xin xing shuju 新興書局, 1978), 3094.

9 Samuel Edgerton's statement is quoted by Mahoney, 'Diagrams and Dynamics', p. 199. Mahoney noted in a footnote an 'outright assertion of a direct causal relation' that Edgerton had made, and further Edgerton went so far as to ask elsewhere: 'Dare we say that Chinese attitudes toward art per se inhibited an indigenous Chinese scientific revolution?' see ibid., p. 218.

10 Kemp, The Science of Art, p. 1.

11 Both Samuel Edgerton and Martin Kemp recognize the central role that perspective played for the entire course of Western art, and even for the sciences. See Edgerton, The Renaissance Rediscovery, pp. 3-4; Kemp, The Science of Art, pp. 7, 53.

12 Kemp, The Science of Art, p. 53.

13 Erwin Panofsky, Perspective as Symbolic Form, trans. Christopher S. Wood (New York, Zone Books, 1991), pp. 13, 40 (quotation here). On page 13, Christopher Wood, the author of the Introduction, writes that 'Naturally Panofsky was selfconscious about his project to write the history of Western art as a history of perspective'.

14 Edgerton, The Renaissance Rediscovery, p. 6.

15 Kemp, The Science of Art, p. 53. Kemp mentions this non-European diffusion of perspective, but his book is confined to the countries within the Western tradition, as he states.

16 Edgerton, The Renaissance Rediscovery, p. 6.

17 The Chinese scholar Cao Yi-qiang has discussed the different ways in which the categories of 'art' and 'science' were recognized in Europe and China in his research on Nian Xiyao’s (年希堯, ?-1739) Shixue 視學 (Theory of Vision) (1729-1735), which is a translation of selections from Andrea Pozzo's Perspectiva (1639-1700). See Cao Yi-qiang, 'An Effort Without a Response: Nian Xiyao (年希堯, ?-1739) and His Study of Scientifc Perspective', I shu shi yanjiu 藝術史研究 (The Study of Art History), 4 (2002), 103-17.

18 Here is cited only a portion of this scholarship, which mostly pays attention to perspective in eighteenth-century China: Elisabeth Corsi 伊麗, 'Qingchao gongting zhong de “yesu huishi toushi lilun” 清朝宮廷中的“耶穌會士透視 理論' (Jesuit Perspective at the Qing Court), in Xiangyu yu duibua: Mingmo qingchu zhongxi wenhua jiaoliu guoji xueshu yantaohui wenji 相遇与對話: 明 末清初中西文化交流國際學术研討會文集 (Encounters and Dialogues: Papers from the International Symposium on Cross-Cultural Exchanges between China and the West in the Late Ming and Early Qing Dynasties), ed. Zhuo Xinping 卓 新平 (Beijing, Zongjiao wenhua chubanshe 宗教文化出版社, 2003), pp. 418-50; Michael Sullivan, 'Some Possible Sources of European Influence on Late Ming and Early Ch'ing Painting', in Proceedings of the International Symposium on Chinese Painting (Taipei, National Palace Museum, 1970), pp. 595-625; Michael Sullivan, The Meeting of Eastern and Western Art, rev. ed. (Berkeley, University of California Press, 1989), pp. 41-87; and again, by the same author, 'The Chinese Response to Western Art', in Studies in the Art of China and South-East Asia, 1 (London, 1991), 311-34; Hu Guanghua 胡光華, 'Chuanjiaoshi yu ming qing zhong xi huihua de jiechu yu chuantong’ 傳教士與明清中西繪畫的接觸與傳通 (Encounters and Exchanges between Missionaries and the Pictorial Traditions of China and the West), Wenhua zazbi 文化雜誌 (Revierw of Culture), 34 (1998), 
109-19; Mayching Kao, 'European Influences in Chinese Art, Sixteenth to Eighteenth Centuries', in China and Europe: Images and Influences in Sixteenth to Eighteenth Centuries, ed. Thomas H. C. Lee (Hong Kong, The Chinese University Press, 1991), pp. 251-303; Fang Hao 方豪, Zhongxi jiaotong shi 中西交通史 (History of Relations between China and the West) (Taipei, Zhongguo wenhua daxue chubanbu 中國文化大學出版部, 1983), II, 907-46; John Ferguson, 'Painters among Catholic Missionaries and Their Helpers in Peking', Journal of the North China Branch of the Asiatic Society, 65 (1934), 20-35.

19 The works of Michael Sullivan and Mayching Kao, as cited above, also support the influence of European art introduced by the Jesuits in the late-Ming period.

20 On the openness of the late-Ming society to foreign visual motifs and technologies, and its particular environment with regard to social viewing and representations, in which perspective was fitted legitimately into cultural demand, see Richard Vinograd, 'Cultural Spaces and the Problem of a Visual Modernity in the Cities of Late Ming Chiang-nan', in Economic History, Urban Culture and Material Culture. Papers from the Third International Conference on Sinology, History Section, ed. Liu T’sui-jung 劉翠溶 and Shih Shou-chieh 石守謙 (Taipei, Institute of History and Philology, Academia Sinica, 2002), pp. 327-60.

21 Cahill, The Compelling Image, p. 71.

22 One recent effort is Hui-Hung Chen, 'Encounters in Peoples, Religions, and Sciences: Jesuit Visual Culture in Seventeenth Century China' (PhD dissertation, Brown University, 2004). The main visual materials discussed in this work are those which can be securely documented in the China missions.

23 Cahill, The Compelling Image, p. 17; Sullivan, 'Some Possible Sources of European Influence', p. 606.

24 Pasquale M. d'Elia, Fonti Ricciane: Documenti originali concernenti Matteo Ricci e la storia delle prime relazioni tra l'Europa e la Cina (1579-1615). Storia dell' introduzione del Cristianesimo in Cina scritta da Matteo Ricci, 3 vols (Roma, 1942-1949), II, 90, 114, 123; Nicolas Trigault, China in the Sixteenth Century: The Journal of Matthew Ricci: 1583-1610, trans. Louis J. Gallagher (New York, Random House, 1953), p. 364. As the Italian sinologist Pasquale D'Elia has pointed out, the old Jesuit Beitang library in Beijing housed two editions of Ortelius's work, one being among the earliest, published in 1570, and the other published in 1595, see D'Elia, Fonti Ricciane, II, 114; C. M. H. Verhaeren (ed.), Catalogue de la Bibliothèque du Pé-tang (1949; reprint, Paris, Belles Lettres, 1969), pp. 688-9 (nos. 2355, 2356).

25 ARSI (Archivum Romanum Societatis Iesu, Rome, Italy), JapSin 13, 177r, quoted by Pasquale M. d'Elia, Le Origini dell'Arte Cristiana Cinese (1583-1640) (Rome, Reale Accademia d'Italia, 1939), p. 80.

26 D'Elia, Fonti Ricciane, II, 192-5.

27 A facsimile of an edition of Gu's Ke zuo zhui yu, in Baibu congshu jicheng 百部叢 書集成, vol. 100 (Taipei, Yi wen yinshuguan 藝文印書館, 1968), orig. p. 19r. Ricci first arrived at Nanjing in 1595.

28 With regard to the early history of perspective in China - as seen in the remarks of Longobardo and Ricci - and the accounts of Chinese admiration for Western chiaroscuro, such as the description in Gu's book, I have discussed them in another article, but for another question regarding 'style' in an intercultural contact, see Hui-Hung Chen, ‘「中國性」的歐洲解釋：耶穌會中國傳教區的「風格」問題 
初探 A European Distinction of Chinese Characteristics: A Style Question in Seventeenth-Century Jesuit China Missions', in Taiwan Journal of East Asian Studies 臺灣東亞文明研究學刊, 5:1 (June 2008), 13-17. The Chinese accounts of the responses - except for Gu's, for example - include those in Jiang Shaoshu's 姜 紹書 Wu sheng shi shi 無聲詩史 (first half of the 17th century) and Zhang Geng's 張庚 (1685-1760) Guo chao hua zheng lu 國朝畫徵錄 (early Qing; early 18th century).

29 For the Jesuit world maps in seventeenth-century China and the Chinese reception of the different visual format they represent, see Hui-Hung Chen, 'The Human Body as a Universe: Understanding Heaven by Visualization and Sensibility in Jesuit Cartography in China', The Catholic Historical Review, 93:3 (July 2007), $517-52$.

30 For the introduction and the whole text of the Astronomia Europaea, see Noël Golvers, The Astronomia Europaea of Ferdinand Verbiest, S.J. (Dillingen, 1687) (Nettetal, Steyler Verlag, 1993). This chapter on perspective and the other two mentioned in my following discussion are on pp.114-17, and this quotation on p. 117.

31 Golvers, The Astronomia Europaea of Ferdinand Verbiest, pp. 116-17, 298-9.

32 This story was also mentioned in several important pieces of literatures, such as J.-B. du Halde, Description de la Chine (Paris, 1735), III, 269; Paul Pelliot, 'La Painture et la gravure Européennes en Chine au temps de Mathieu Ricci', T'oung Pao, 20 (1921), 5; Louis Pfister, Notices biographiques et bibliographiques sur les Jesuites de l'ancienne mission de Chine, 1552-1773, 2 vols (Shanghai, Imprimerie de la Mission Catholique, 1932), I, 238. Verbiest's comments are from Golvers, The Astronomia Europaea of Ferdinand Verbiest, p. 117.

33 Noël Golvers, François de Rougemont, S.J., Missionary in Ch'ang-shu (Chiangnan): A study of the Account Book (1674-1676) and the Elogium (Leuven, Leuven University Press/Ferdinand Verbiest Foundation, 1999), p. 480.

34 For the following discussion of this work and other details about it, see Chen, 'Encounters in Peoples', pp. 231-357.

35 Nadal's Evangelical History was requested several times in Jesuit letters for use in the China mission. Niccolò Longobardo's letter of 1598, as mentioned above, is also the earliest account that officially asks for Nadal's book for the China mission.

36 With regard to the print 'Cure of the Centurion's Servant', the second figure from the left and three others in Jesus's entourage are depicted completely in the dark in Nadal's print, in contrast to the other figures, which are rendered through a forceful three-dimensional use of chiaroscuro. This contrast is completely removed in Aleni's woodcut, which depicts all of the figures from the same source of light. Thus Nadal's strong chiaroscuro effect is replaced by a linear depiction without the importance of light and shade. For a detailed discussion of the above, see Chen, 'A European Distinction of Chinese Characteristics', p. 20.

37 The other two images with extra openings are 'The Rich Man and Lazarus' and 'Mary Magdalen Anoints Jesus's Feet'. The print 'Washing the Feet at the Last Supper' has the addition of a Chinese-landscape screen, in contrast to the blankness of the stone wall in Nadal's engraving.

38 Grayson, On Painting, p. 54.

39 Panofsky, Perspective as Symbolic Form, pp. 27, 75-6. 
40 Richard Vinograd pointed out a 'landscape window', which had developed in late-Ming China, to show a living painting, so to speak, in an interior space by changing the 'scenery' (i.e. the painting) with days or seasons. This is a case Vinograd discusses to explain the enjoyment of visual technologies in the lateMing society. See Vinograd, 'Cultural Spaces and the Problem', pp. 341-2.

41 They are the 'Birth of John the Baptist Preceding Christ', 'Wedding Feast at Cana', 'Curing Peter's Mother-in-law', 'Mary Magdalen Anoints Jesus's Feet', 'Washing the Feet at the Last Supper', 'Holy Sacrament', 'Descent of the Holy Spirit', and 'Apparition to the Holy Mother'. The above eight prints do not include some of Nadal's other originals, which also depict a tiled floor.

42 This point of view has been discussed in my article, Chen, 'The Human Body as a Universe'. In addition, as mentioned above, the accounts of Jiang Shaoshu and Zhang Geng are both concerned with the religious images Ricci showed to the Chinese.

43 Samuel Y. Edgerton, The Heritage of Giotto's Geometry: Art and Science on the Eve of the Scientific Revolution (Ithaca, Cornell University Press, 1991), pp. 256, 261. On p. 256, the author says: 'Nadal's pictures would recapitulate the life of Christ with scientific objectivity'.

44 For this European background see Claire Farago (ed.), Reframing the Renaissance: Visual Culture in Europe and Latin America 1450-1650 (New Haven, Yale University Press, 1995), pp. 9-12.

45 For European scientia in Ming-Qing China, see Benjamin A. Elman, On Their Own Terms: Science in China, 1550-1900 (Cambridge, Mass., Harvard University Press, 2005), pp. 107-49.

46 Standaert's words are quoted from his article, 'The Classification of Sciences and the Jesuit Mission in Late Ming China', in Linked Faiths: Essays on Chinese Religions E Traditional Culture in Honour of Kristofer Schipper, ed. Jan A. M. De Meyer and Peter M. Engelfriet (Leiden, Koninklijke Brill NV, 2000), p. 289. A modern reprint of the Ming li tan was published in Taipei in 1975, see Fu Fanji 傅氾際 (Francisco Furtado), trans., Ming li tan 名理探 (On Philosophy), 2 vols (Taipei, Taiwan shangwu yinshuguan 臺灣商務印書館, 1975). The 'philosophy' in the English translation of this title was based on the opening sentence of Furtado's text, and Adrian Dudink specified this as a work on 'Aristotelian logics', see Adrian Dudink, 'The Zikawei (徐家匯) Collection in the Jesuit Theologate Library at Fujen 輔仁 University (Taiwan): Background and Draft Catalogue’, Sino-Western Cultural Relations Journal, 18 (1996), 19.

47 Standaert, 'The Classification of Sciences', p. 289.

48 For the original documents of Nadal's proposal (1552) about the study plan of the Collegio Romano, and a detailed discussion of the Jesuit mathematical study in this period, when Jesuit pedagogy was being formulated, see Antonella Romano, Le Contre-réforme mathématique: constitution et diffusion d'une culture mathématique jésuite à la Renaissance (1540-1640) (Rome, École française de Rome, 1999), pp. 35-83; documents mentioned above appear on pp. 52-3 and 72-6.

49 For Chapter 12 of the Constitution of the Society, whose title is 'The Branches to be Taught in the University of the Society', see George E. Ganss, S.J. (ed.), Ignatius of Loyola: The Spiritual Exercises and Selected Works (New York, Paulist Press, 1991), pp. 297-9; for the Ratio Studiorum, see Ratio Atque Institutio Studiorum Societatis Iesu: Ordinamento degli Studi della Compagnia di Gesù, 
trans. Angelo Bianchi (Milano, Biblioteca Universale Rizzoli, 2002), p. 207 (on 'Regulae Professoris Mathematicae'); The Jesuit Ratio Studiorum of 1599, trans. Allan P. Farrell, S.J. (Washington, DC, Conference of Major Superiors of Jesuits, 1970), p. 46; Romano, Le Contre-réforme mathématique, pp. 85-132; Giuseppe Cosentino, 'Le Matematiche nella 《Ratio Studiorum》della Compagnia di Gesu', in Miscellenea storica ligure, 2 (Genova, 1970), 171-213.

50 ARSI, JapSin 13-I, 94v. Here the author expresses gratitude to Liam Brockey for his help in reading and discussing this Portuguese passage. Interesting to note is that the year of this source, 1597, is earlier than the year that was fixed for the final version of the Ratio Studiorum.

51 For Jesuit education and its significance in their worldly missions, especially with regard to cross-cultural engagements, the following books both present this perspective: I Gesuiti e la Ratio Studiorum (Roma, Bulzoni Editore, 2004), esp. p. 9; Christopher Chapple (ed.), The Jesuit Tradition in Education and Missions: A 450 Year Perspective (Scranton, Pennsylvania, 1993). Both works praise the Jesuit global demonstration, by mentioning its extension to China or the Far East, but both also ignore, intentionally or unintentionally, that the case of China cannot be examined along with the subject of Jesuit formal education.

52 Chapple, The Jesuit Tradition, p. 7.

53 Standaert, 'The Classification of Sciences', pp. 287-317.

54 Giulio Aleni, Xixue fan 西學凡 (Introduction to Western Studies), in Tianxue chuban 天學初函, 6 vols (Taipei, Taiwan xuesheng shuju 台灣學生書局, 1964), I, 9-60. This facsimile is an edition housed at the Biblioteca Apostolica Vaticana (BAV), Vatican City.

55 Elisabetta Corsi, 'Insegnare la Prospettiva Lineare in Cina: Trattati Europei di Prospettiva nella Biblioteca dei Gesuiti di Bei Tang', Archives Internationales d'Histoire des Sciences, 52 (148) (June 2002), 127-9.

56 J. V. Field, 'Perspective and the Mathematicians: Alberti to Desargues', in Mathematics from Manuscripts to Print, 1300-1600, ed. Cynthia Hay (Oxford, Oxford University Press, 1988), pp. 237-46; the quotation is on p. 244. Field also said that, no matter what were the developments of artistic perspective from the fifteenth to the sixteenth centuries, it did not cease to be a part of the branch of natural philosophy; that is, of the science of vision (optics, or mathematical perspective).

57 The Beitang collection refers to an old European book trove in Beijing, the capital of China, dating from Ricci's period. This collection is valuable for an understanding of the actual contents of the cultural encounters between Europe and China resulting from the contacts of Jesuit missionaries, over the course of the years from 1583 to 1773 . Edgerton said that nineteen titles on perspective are in the Beitang, but there are actually more, as the List shows. Edgerton, The Heritage of Giotto's Geometry, p. 261.

58 Edgerton, The Renaissance Rediscovery, p. 77.

59 Field, 'Perspective and the Mathematicians', pp.248-60; the quotation is on p. 260.

60 Regarding Pozzo and the partial Chinese translation of Pozzo's Perspectiva in the eighteenth century, the research in the works of Professor Corsi is among the most prominent and detailed, see Corsi, 'Insegnare la Prospettiva Lineare in Cina', pp. 122-42: this article also discusses some of the works in the List of the Beitang collection; and by the same author, La Fábrica de las ilusiones: los jesuitas $y$ la difusión de la perspectiva lineal en China (1698-1766). [Perspectiva pictorum 
et architectorum. Selections. Spanish \& Chinese] (Mexico, D. F., El Collegio de México, 2004). Also Cao, 'An Effort Without a Response', pp. 103-33. As for Jan Vredeman de Vries, see Adolf K. Placzek's introduction to a modern facsimile of Vredeman's Perspective: Jan Vredeman de Vries Perspective (New York, Dover Publications, Inc., 1968), and Kemp, The Science of Art, pp. 109-12.

61 Grayson, On Painting, p. 44.

62 Paul Hills, The Light of Early Italian Painting (New Haven, Yale University Press, 1987), pp. 64-71.

63 Edgerton, The Heritage of Giotto's Geometry, pp. 225-30.

64 Giulio Aleni, Xingxue cushu 性學觕述 (On Human Nature), in Nicolas Standaert and Adrian Dudink, 耶穌會羅馬檔案館明清天主教文獻: Chinese Christian Texts from the Roman Archives of the Society of Jesus, 12 vols (Taipei, Taipei Ricci Institute, 2002), VI, 187.

65 Chen, 'A European Distinction of Chinese Characteristics', pp. 17-18.

66 Wang Keyu 汪砢玉, Shanbu wang minghua tiba 珊瑚網名畫題跋, in Shiyuan congshu 適園叢書 (Taipei, Yiwen yinshuguan 藝文印書館, n.d.), X, 31r. This account was first noted and translated by Michael Sullivan, who said in an endnote that he was indebted to James Cahill; see Sullivan, 'Some Possible Sources of European Influence', pp. 598-9. Here the translation is mine. Sullivan translated the place Zhangnan as on the South Bank of the Wei River in Shangtung [Shandong 山東], but a more direct transliteration should point to the Prefecture of Zhangzhou 漳州 in Fujian.

67 Sullivan, 'Some Possible Sources of European Influence', p. 598.

68 D'Elia, Fonti Ricciane, II, 123, 125.

69 This source is cited and the quotation here is translated by Liam M. Brockey, Journey to the East: The Jesuit Mission to China, 1579-1724 (Cambridge, Mass., The Belknap Press of Harvard University Press, 2007), p. 307.

70 Panofsky, Perspective as Symbolic Form, pp. 28-30.

71 Ibid., p. 72, from which both quotations come.

72 Originally from Bacon's Opus majus, this quotation is taken from Edgerton's The Renaissance Rediscovery, pp. 74-5.

73 Ibid., p. 75 (both quotations herein).

74 Peter Canisius, A Summa of Christian Doctrine [1592-96] (Menston, England, Scolar Press, 1971), pp. 596-7.

75 The original source is about the mission of the Jesuit Jacques le Faure, which was reported in the annual letter for 1658-1660, and cited by Brockey, Journey to the East, p. 327.

76 For the late-Ming fondness for varieties of visualization such as reality vs. illusion, see Vinograd, 'Cultural Spaces and the Problem', esp. pp. 350, 354.

77 Corsi, 'Insegnare la Prospettiva Lineare in Cina', p. 129.

78 Field, 'Perspective and the Mathematicians', p. 246.

79 Michael Kubovy, 'Twice Blessed: A Renaissance Perspective on Human Perception', Sciences-New York, 29:6 (November-December 1989), 38-9; Field, 'Perspective and the Mathematicians', pp. 236-63.

80 This English quotation of Dubreuil and the discussion of it are indebted to Corsi, 'Insegnare la Prospettiva Lineare in Cina', p. 122. Dubreuil's work, La Perspective practique was published in Paris in 1642.

81 Johann Adam Schall von Bell, Yuan jing shuo 遠鏡說 (On the Telescope), in 
Congshu jicheng chubian 叢書集成初編 (The First Compilation of Various Books) (Shanghai, Shangwu yinshuguan, 1936), pp. 13-14, 30-1. One of the methods should point to the employment of the camera obscura. As Jonathan Crary has suggested, the camera obscura shows a much broader kind of 'subject-effect', and perspective is more just about picture-making of a two-dimensional representation. See Jonathan Crary, Techniques of the Observer: On Vision and Modernity in the Nineteenth Century (Cambridge, Mass., MIT Press, 1990), p. 34.

82 Han Lin 韓霖, and Zhang Geng 張賡, Sheng jiao xin zheng 聖教信證 (Belief in and Confirmation of the Sacred Religion), in Tianzhujiao dongchuan wenxian sanbian 天主教東傳文獻三編 (Literature of Catholicism in the East, Third Series), 6 vols (Taipei, Taiwan xuesheng shuju 台灣學生書局, 1966), I, 280-1.

83 Willard Peterson, 'From Interest to Indifference: Fang I-Chih and Western Learning', Ch'ing-shib wen-t'I, 3:5 (November 1976), 77. See also the more recent detailed research in Elman, On Their Own Terms, pp. 107-18; esp. p. 111 on the late Ming literatus Fang Yizhi 方以智 (1611-71).

84 Benjamin A. Elman, From Philosophy and Philology: Intellectual and Social Aspects of Change in Late Imperial China (Cambridge, Mass., Harvard University Press, 1984), p. 34.

85 The above quotation comes from Cahill, The Compelling Image, p. 35.

86 A passage explaining a realistic school of Chinese portraiture and this key point can be found in Li Tou 李斗, Yangzhou bua fang lu 揚州畫舫錄 (Account of the Paintings of Yangzhou) (printed in 1795); a facsimile is published by Taipei (Taipei, Xuehai shuju 學海書局, 1969), pp. 139-43.

87 Wen C. Fong, Beyond Representation: Chinese Painting and Calligraphy 8th-14th Century (New York, Metropolitan Museum of Art, 1992), pp. 3-4; quoted by David Carrier, 'Meditations on a Scroll, or the Roots of Chinese Artistic Form', Word and Image, 18:1 (January-March 2002), 47.

88 E. H. Gombrich, Art and Illusion: A Study in the Psychology of Pictorial Representation (Oxford, Phaidon Press, 1960), pp. 29-54, esp. pp. 29, 44, 53.

89 For a general and thoughtful comparative analysis of the different artistic traditions between China and Europe, see Wen C. Fong, 'Why Chinese Painting Is History', The Art Bulletin, 85 (June 2003), 258-80; Carrier, 'Meditations on a Scroll', pp. 45-52; Craig Clunas, Pictures and Visuality in Early Modern China (Princeton, Princeton University Press, 1997), pp. 9-24.

\section{Address for Correspondence}

Dr Hui-Hung Chen, Department of History, National Taiwan University, No. 1 Roosevelt Road Section 4, Taipei 10617, Taiwan, email: huihung@ntu.edu.tw 